Zeszyty Naukowe Szkoły Głównej Gospodarstwa Wiejskiego w Warszawie

Problemy Rolnictwa Światowego tom 19 (XXXIV), zeszyt 1, 2019: 144-152

DOI: 10.22630/PRS.2019.19.1.13

Barbara Wieliczko ${ }^{1}$

Instytut Ekonomiki Rolnictwa i Gospodarki Żywnościowej - Państwowy Instytut

Badawczy

\title{
Federalizm fiskalny i środowiskowy a polityka rolna
}

\section{Fiscal and Environmental Federalism vs. Agricultural Policy}

\begin{abstract}
Synopsis. Stworzenie przez państwo skutecznej i efektywnej polityki rolnej jest niezmiernie trudnym zadaniem. Wydaje się, że zaprojektowanie właściwego zestawu instrumentów staje się tym trudniejsze im większego obszaru dotyczy. Celem artykułu jest próba odpowiedzi na pytanie, jak wielką rolę w tworzeniu i realizacji polityki rolnej w UE powinna odgrywać Komisja Europejska, a jak dużą rządy poszczególnych państw członkowskich. Odpowiedź na to pytanie bazuje na osiągnięciach teorii federalizmu fiskalnego i federalizmu środowiskowego. Artykuł opiera się na przeglądzie literatury oraz analizie optymalnego z punktu widzenia celów polityki rolnej zakresu kompetencji administracji publicznej w tworzeniu i wdrażaniu polityki rolnej przy uwzględnieniu aktualnych wyzwań stojących przed rolnictwem. Uzyskane wyniki pozwalają określić, jak zoptymalizować podział zadań związanych z polityką rolną między szczeblami administracji, co umożliwia wdrażanie skuteczniejszej i efektywniejszej polityki rolnej.
\end{abstract}

Słowa kluczowe: polityka rolna, federalizm fiskalny, federalizm środowiskowy, skuteczność polityki, efektywność polityki

\begin{abstract}
The creation of an effective and efficient agricultural policy by the state is an extremely difficult task. It seems that designing proper agricultural policy becomes more difficult the larger the area. The aim of the article is to try to answer the question of what role in the creation and implementation of agricultural policy in the EU should be played by the European Commission, and by individual Member States. The answer to this question is based on the theories of fiscal and environmental federalism. The article is based on a review of literature and analysis of the optimal scope of public administration's competences in the creation and implementation of agricultural policy. The obtained results allow to determine how to optimize the division of tasks related to the agricultural policy between the levels of administration, which enables the implementation of a more effective and more efficient agricultural policy.
\end{abstract}

Key words: agricultural policy, fiscal federalism, environmental federalism, policy effectiveness, policy efficiency

JEL Classification: Q18, Q58, H77

\section{Wprowadzenie}

Stworzenie przez państwo skutecznej i efektywnej polityki rolnej jest niezmiernie trudnym zadaniem. Zarówno w procesie projektowania, jak i wdrażania tej polityki pojawia się bardzo dużo dylematów i problemów związanych z niepewnością, co do przyszłych skutków instrumentów przewidywanych do implementacji. Wydaje się, że zaprojektowanie właściwej polityki rolnej staje się tym trudniejsze im większego obszaru dotyczy. Wynika

${ }^{1}$ dr, IERiGŻ-PIB, ul. Świętokrzyska 20,00-002 Warszawa, e-mail: Barbara.Wieliczko@ierigz.waw.pl; https://orcid.org/0000-0003-3770-0409 
to z faktu, iż wraz ze wzrostem obszaru objętego wdrażaniem określonego instrumentarium polityki rolnej, zwiększa się zróżnicowanie rolnictwa i specyfika jego otoczenia.

Zjawisko to jest szczególnie widoczne przy analizowaniu funkcjonowania polityki rolnej w Unii Europejskiej. Kolejne rozszerzenia obejmowały państwa o odmiennej strukturze rolnictwa i różnych warunkach społeczno-przyrodniczych, w których funkcjonuje ten sektor. W związku z tym jednolite instrumentarium wspólnej polityki rolnej (WPR) stało się niedopasowane do odmiennych potrzeb sektora rolnego w poszczególnych państwach członkowskich.

Celem artykułu jest próba odpowiedzi na pytanie, jak wielką rolę w tworzeniu i realizacji polityki rolnej w Unii Europejskiej powinna odgrywać Komisja Europejska, a jak dużą rządy poszczególnych państw członkowskich. Pytanie to nie ogranicza się jednak do tego szczególnego przypadku. Zarówno to pytanie, jak i odpowiedź na nie mają charakter bardziej uniwersalny i odnoszą się do podziału zadań i obowiązków w zakresie działań władz centralnych i regionalnych funkcjonujących w ramach wspólnego, jednolitego rynku wewnętrznego $\mathrm{i}$ unii handlowej ${ }^{2}$. Odpowiedź na to pytanie bazuje na osiagnnięciach teorii federalizmu fiskalnego i federalizmu środowiskowego.

Artykuł opiera się na przeglądzie literatury dotyczącej stosowania federalizmu fiskalnego oraz federalizmu środowiskowego w polityce państwa oraz analizie optymalnego z punktu widzenia celów polityki rolnej zakresu kompetencji administracji publicznej w tworzeniu i wdrażaniu polityki rolnej przy uwzględnieniu aktualnych wyzwań stojących przed rolnictwem. Uzyskane wyniki pozwalają określić, jak zoptymalizować podział zadań związanych z polityką rolną między różnymi szczeblami administracji, co umożliwia wdrażanie skuteczniejszej i efektywniejszej polityki rolnej.

\section{Federalizm fiskalny i środowiskowy}

Punktem wyjścia do rozwoju teorii federalizmu fiskalnego oraz federalizmu środowiskowego była koncepcja konkurencji między jurysdykcjami. W 1956 roku Tiebout zaproponował model konkurencji różnych jurysdykcji o mieszkańców. Stwierdził, iż konkurując o mieszkańców poszczególne jednostki administracyjne dostosują swoje wydatki do preferencji mieszkańców, co optymalizuje wydatki. Jak wskazuje praca Banzhafa i Walsha (2006), model Tiebouta należy uznać za właściwy. Co więcej, autor ten wykazał, iż preferencje mieszkańców dotyczą także środowiskowych dóbr publicznych.

W przypadku federalizmu środowiskowego fundamentalnym problemem jest kwestia środowiskowych dóbr publicznych o różnej skali „oddziaływania”. Możemy mieć do czynienia z dobrami publicznymi o charakterze krajowym, jak i lokalnym, co wpływa na

\footnotetext{
${ }^{2} \mathrm{~W}$ niniejszym artykule w celu zapewnienia pewnej dozy uniwersalności wyników mowa jest o władzy centralnej w opozycji do władzy regionalnej. Chodzi tu nie tylko o obszar jednego państwa. Może to dotyczyć podziału kompetencji nie tylko między władzą centralną i regionami (czy jak w Stanach Zjednoczonych instytucjami federalnymi i stanowymi), ale także niższego szczebla administracji, tj. władz regionalnych i lokalnych (np. w Polsce władz szczebla wojewódzkiego i powiatowego) oraz wyższego szczebla - grupa państw a państwo (np. Unia Europejska a państwa członkowskie czy porozumienia międzynarodowe - np. Protokół z Kioto a państwa sygnatariusze). Oczywiście możliwości podziału kompetencji między różnymi wymienionymi szczeblami władz są bardzo różne i zależą od obowiązujących regulacji prawnych. Przy tym, należy pamiętać, iż obowiązujące rozwiązania mogą być zmieniane, co może okazać się konieczne dla zapewnienia optymalnego podziału kompetencji związanych z danym obszarem polityki.
} 
ich wartość mierzoną na różnym poziomie administracji. Federalizm środowiskowy to także kwestia efektu rozlewania się efektów działań podejmowanych na jednym obszarze na okoliczne obszary. Jest to szczególnie istotny problem wymagających szczególnej uwagi przy podziale kompetencji poszczególnych szczebli administracji.

Jednocześnie $\mathrm{w}$ przypadku kwestii środowiskowych mamy często do czynienia z efektem skali, gdy objęcie określonymi działaniami większego obszaru lepiej służy ochronie środowiska niż ograniczenie się do mniejszej jednostki administracyjnej. Dotyczy to przede wszystkim sytuacji, gdy ochroną czy określonymi działaniami prośrodowiskowymi obejmuje się jedynie fragment danego ekosystemu ${ }^{3}$. W tym przypadku możemy mówić o efekcie skali realizowanych działań ${ }^{4}$.

Jak na podstawie przeglądu literatury na temat federalizmu środowiskowego Steurer i Clar (2015), stwierdzili, że federalne systemy polityczne mogą utrudniać ograniczanie zmian klimatycznych na pięć różnych sposobów. Po pierwsze, duża liczba podejmujących decyzje i związane z tym duplikowanie się instytucji może prowadzić do opóźnienia wdrażania działań służących ochronie środowiska lub ich blokowania. To podnosi koszty transakcyjne polityki środowiskowej i zmniejsza jej efektywność. Po drugie, może dojść do rywalizacji między poszczególnymi regionami służącej podniesieniu ich konkurencyjności ekonomicznej, co może doprowadzić do obniżenia norm i standardów środowiskowych. Po trzecie, rozdrobnienie odpowiedzialności między poszczególnymi poziomami władz może prowadzić do fragmentarycznej i niespójnej polityki środowiskowej. Po czwarte, system federacyjny może utrudniać wdrażanie postanowień porozumień międzynarodowych. Po piąte, niejasny lub niewłaściwy podział obowiązków między poszczególne szczeble administracji może utrudnić wdrażanie regulacji środowiskowych.

Jednakże federalna struktura państwa nie musi wiązać się z problemem realizacji zadań dotyczących ochrony środowiska. Federalna struktura państwa może umożliwiać eksperymentowanie z różnymi rozwiązania i wybór optymalnej formy ochrony środowiska. Możliwe jest również rozprzestrzenianie się innowacji środowiskowych. Wypracowane lokalnie rozwiązania mogą rozprzestrzeniać się na inne regiony, ale konieczne jest do tego nadanie odpowiednich uprawnień lokalnym aktorom, co nie zawsze ma miejsce w ramach federacyjnej struktury państwa (Corfee Morlot, 2009). Główną zaletą federalizmu jest jednak elastyczność rozwiązań w zakresie ochrony środowiska i dopasowanie ich do potrzeb danego regionu.

Interesujaccym kierunkiem rozwoju teorii federalizmu środowiskowego jest uwzględnienie $\mathrm{w}$ proponowanych rozwiązaniach koncepcji federalizmu adaptacyjnego oraz eksperymentalizmu demokratycznego. Eksperymentalizm demokratyczny (ang. democratic experimentalism) to element współczesnej myśli prawniczej bazujący na pragmatycznej teorii społecznej (ang. pragmatist social theory) i innowacyjnych rozwiązaniach

\footnotetext{
${ }^{3}$ Przykładem, na mniejszą skalę jest kwestia działań rolno-środowiskowych, gdy podjęcie działania, zwłaszcza z zakresu ochrony bioróżnorodności w jednym gospodarstwie rolnym nie daje znaczących efektów, jeśli działanie to nie obejmie również sąsiednich gospodarstw. W związku z tym wielu badaczy postuluje grupowe czy też kolektywne wdrażanie działań rolno-środowiskowych (np. Merckx i in., 2009; Wieliczko 2015; Kleijn i in., 2011; Prager, 2015; McKenzie i in., 2013; Toderi i in., 2017).

${ }^{4}$ W literaturze anglojęzycznej mowa jest tu o „ecologies of scale” w analogii do „economies of scale”, czyli ekonomicznego efektu skali (np. Adler 2005, s.15).
} 
stosowanych w różnych post-biurokratycznych organizacjach. Zakłada współpracę, a nie wzajemne dowodzenie swych racji w oparciu o rozkazy czy techniki inżynierii politycznej ${ }^{5}$.

Innym, bardzo praktycznym rozwiązaniem w zakresie federalizmu środowiskowego jest koncepcja federalizmu progresywnego. Oznacza ona określenie norm i wymogów minimalnych na poziomie centralnym z możliwością zaostrzenia ich na szczeblu regionalnym (Dijkstra, Fredriksson, 2010).

Ważnym problemem, zarówno $\mathrm{w}$ przypadku federalizmu środowiskowego, jak i fiskalnego, jest asymetria informacji. Nie można zakładać, iż władze na wyższym szczeblu dysponują pełną wiedzą o preferencjach mieszkańców poszczególnych regionów lub w pełni znają problemy środowiskowe na szczeblu regionów.

\section{Jaki zakres federalizmu potrzebny jest w polityce rolnej?}

Polityka rolna obejmuje $\mathrm{w}$ coraz większym stopniu nie tylko cele związane $\mathrm{z}$ produkcją żywności oraz zapewnieniem odpowiedniego poziomu dochodów ludności rolniczej, ale także z ochroną środowiska i dostarczaniem dóbr publicznych w formie usług ekosystemów. Z tego względu kwestia federalizmu środowiskowego nabiera coraz większego znaczenia, jeśli chodzi o optymalizację oddziaływania polityki rolnej. Ponadto, w dobie rosnącej globalizacji procesów ekonomicznych, także kwestie federalizmu fiskalnego w polityce rolnej stają się istotniejsze z punktu widzenia potrzeb rozwojowych sektora rolnego.

Jak wskazuje Oates (2001), istnieje obawa, iż władze regionalne mogą być bardziej skłonne do rezygnacji z celów środowiskowych swojej polityki z uwagi na dążenie do realizacji celów ekonomicznych, a zwłaszcza przyciagania inwestorów, niż władze wyższego szczebla, co może się przekładać na mniej restrykcyjne wymogi związane z ochroną środowiska. W efekcie może to generować większe zanieczyszczenie i degradację środowiska, co może dotyczyć także obszarów okolicznych regionów. Jednocześnie jednak również rozwiązania centralne mogą nie być optymalne, gdyż zazwyczaj są jednakowe dla całego obszaru, co w zależności od przyjętych rozwiązań może oznaczać, iż są one $\mathrm{w}$ danym regionie nadmiernie i niepotrzebnie zbyt restrykcyjne lub też może prowadzić do wprowadzania regulacji, które nie są wystarczająco skuteczne z punktu widzenia pożądanych efektów środowiskowych. Idealnym przykładem tej ostatniej sytuacji jest tzw. zazielenienie wprowadzone w ramach unijnego systemu dopłat bezpośrednich. Jak pokazały wyniki audytu przeprowadzonego przez Europejski Trybunał Obrachunkowy (2017) i podsumowane w tytule opublikowanego przez tę instytucję raportu, zazielenienie to „bardziej złożony system wsparcia dochodów, który nie jest jeszcze skuteczny pod względem środowiskowym". Natomiast wyniki licznych badań (np. Van Zeijtisa i in., 2011; Solazzo i in., 2016; Cortignani, Severini, Dono, 2017; Gocht i in., 2017), oddziaływanie tego instrumentu na środowisko jest niewielkie, choć generalnie pozytywne. Biorąc pod uwage koszty administracyjne związane $\mathrm{z}$ wprowadzeniem zazielenienia, to instrument ten należy uznać za nieskuteczny i nieefektywny.

Realizacja działań związanych ze środowiskiem przyrodniczym jest bardzo złożona. Konieczna jest bardzo szczegółowa wiedza ekspertów z różnych dziedzin, aby kompleksowo chronić środowisko i zapobiegać lub ograniczać negatywne skutki działalności człowieka. Co

\footnotetext{
${ }^{5}$ Szersze omówienie podstaw eksperymentalizmu demokratycznego znajduje się m.in. w publikacji Sabel i
} Simona (2017). 
więcej, zakres i charakter niezbędnych działań są bardzo zróżnicowane w zależności od stanu danego ekosystemu i jego specyfiki. Z tego względu najwłaściwszym rozwiązaniem jest opracowywanie szczegółowych regulacji i instrumentów na poziome spójnych, jednolitych ekosystemów. Oznacza to poziom administracji niższy niż poziom państwa.

Jak stwierdził Karkkainen (2002) „rozsądne zarządzanie środowiskiem musi mieć charakter lokalny lub/i regionalny i dostosowany do specyfiki danego ekosystemu". Biorąc pod uwagę fakt, iż typ i sposób prowadzenia działalności rolniczej są w znacznym stopniu zdeterminowane przez ekosystem, w którym funkcjonuje dane gospodarstwo, to i polityka rolna powinna uwzględniać tę specyfikę, a więc mieć charakter lokalny lub regionalny. Z drugiej strony, zwłaszcza uwzględniając federalizm fiskalny i zasadę subsydiarności nie sposób ograniczyć jej do poziomu lokalnego, a nawet regionalnego. W szczególności jest to związane z kwestią występowania różnego typu obszarów z ograniczeniami, czyli miejsc, w których prowadzenie działalności rolniczej napotyka na specyficzne niekorzystne warunki, zwłaszcza przyrodnicze, i w związku z tym wydajność prowadzonej tam działalności rolniczej jest niższa niż na obszarach o korzystnych warunkach. Biorąc pod uwagę fakt, iż zazwyczaj występowanie obszarów niekorzystnych dla działalności rolniczej jest skorelowane $\mathrm{z}$ występowaniem niskiego poziomu rozwoju społeczno-gospodarczego w porównaniu do reszty kraju, to problemy rolnictwa nie mogą być skutecznie rozwiązane na poziomie takiego regionu $\mathrm{z}$ uwagi na ograniczenia budżetowe.

Natomiast Ferrara i inni (2014) na podstawie analizy modelu wskazują iż niekoniecznie konkurencja regionów o napływ kapitału i inwestycji musi prowadzić do obniżenia podatków środowiskowych i jeszcze większej eksploatacji środowiska naturalnego. Możliwe jest też podnoszenie standardów dbałości o środowisko. To w którym kierunku na standardy ochrony środowiska będzie oddziaływać związana $\mathrm{z}$ federalizmem konkurencja między regionami zależy od tego jak duża czesść zanieczyszczeń ma charakter transgraniczny i jaki jest stopień zróżnicowania przewag komparatywnych między regionami. Jeśli różnice w produktywności są duże, zaś mała część zanieczyszczeń rozprzestrzenia się poza granicami regionu, w którym zostały wygenerowane, to federalizm prowadzi do mniejszych strat $\mathrm{w}$ stanie środowiska naturalnego, niż rozwiązania o charakterze centralnym.

Istnieje jeszcze jedno rozwiązanie, szczególnie ważne w odniesieniu do kwestii środowiskowych, które można zastosować w odniesieniu do optymalizacji zakresu zadań między władzą centralną i regionalną. Chodzi o współpracę kilku regionów. Jednakże tego typu współpraca sama w sobie jest znacznym wyzwaniem (Oates, 2001).

W przypadku unijnej wspólnej polityki rolnej można również rozważać problem właściwego podziału zadań i kompetencji poszczególnych szczebli administracji. WPR z założenia miała być wspólną polityką i oferowała jednakowe instrumenty wszystkim państwom członkowskim. Z czasem, gdy rozwinął się filar 2 WPR pojawiła się możliwość wybierania przez państwa członkowskie instrumentów polityki rozwoju obszarów wiejskich, które wdrażają w ramach swoich programów rozwoju obszarów wiejskich. Reforma systemu płatności bezpośrednich, która weszła w życie w 2015 roku zwiększyła zakres swobody państw członkowskich pozwalając na wybór spośród opcjonalnych kategorii płatności. W rezultacie doprowadziło to do tego, że nie ma dwóch państw, które miałyby tak samo ukształtowany system płatności bezpośrednich. Rozwiązanie to wprowadzono mając na względzie zróżnicowanie rolnictwa i jego potrzeb rozwojowych, które występują między państwami członkowskimi.

Propozycje Komisji Europejskiej dotyczące funkcjonowania WPR w latach 2021-2027 idą jeszcze bardziej w kierunku zwiększenia roli państw członkowskich w kształtowaniu 
instrumentarium WPR. Propozycja ta wynika $\mathrm{z}$ tego, że zdaniem KE „w niezwykle zróżnicowanych warunkach rolniczych i klimatycznych w Unii ani podejście odgórne, ani uniwersalne nie jest jednak odpowiednim rozwiązaniem, które zapewniłoby osiagnięcie pożądanych rezultatów i europejskiej wartości dodanej” (European Commission, 2018, s. 3). W związku z tym KE zaproponowała nowy model wdrażania WPR, w którym „Unia określa podstawowe parametry polityki (cele WPR, szeroko rozumiane rodzaje interwencji, podstawowe wymogi), natomiast odpowiedzialność spoczywa w większej mierze na państwach członkowskich, które są w większym stopniu rozliczane ze sposobu realizacji celów (...)" (European Commission, 2018, s. 3).

Zaproponowane zmiany są różnie oceniane. Większość pozytywie odnosi się do samej idei zwiększenia roli państw członkowskich w projektowaniu palety instrumentów WPR, jednakże pojawia się również obawa, o to, jak w praktyce będą mogły funkcjonować te rozwiązania. $Z$ jednej strony unijne cele mogą doprowadzić do tego, iż faktycznie nie nastapi zasadnicze zwiększenie roli państw członkowskich. Być może czeka je jedynie trudniejsze niż dotychczas zadanie żonglowania między wymogami wyznaczonymi przez unijne regulacje i krajowymi potrzebami rolnictwa, co będzie oznaczało faktyczny brak zmiany systemu. Z drugiej zaś strony zwiększenie roli państw członkowskich może zagrozić funkcjonowaniu jednolitego rynku UE, gdyż rolnicy w poszczególnych państwach mogą być objęci innymi wymogami, które generując odmienne koszty, a co za tym idzie mają wpływ na konkurencyjność rolnictwa.

Wydaje się, iż wśród interesariuszy ta druga obawa jest mniej popularna. Jednakże i takie głosy się pojawiaja. Przykładem jest opinia Zgromadzenia Narodowego Francji (National Assembly, 2018). Autorzy tej opinii stwierdzili, iż projekt wspomnianego już rozporządzenia przedstawionego przez KE narusza zasadę pomocniczości obowiązującą w UE i grozi zakłóceniem konkurencyjności w sektorze rolnym. Uznano także, iż WPR w swoim obecnym kształcie jest już wystarczająco elastyczna, aby uwzględnić specyfikę poszczególnych państw członkowskich. Ponadto wskazano, iż proponowane rozwiązania pozbawiłyby UE możliwości definiowania prawdziwie wspólnej polityki rolnej, która stałaby się ,jedynie ciałem koordynującym dwadzieścia siedem różnych polityk rolnych” (National Assembly, 2018, s. 3).

Kolejną obawą podnoszoną zwłaszcza w kontekście celów środowiskowych, jest kwestia sposobu, w jaki KE zamierza weryfikować plany państw członkowskich. Jak wskazuje Europejski Trybunał Obrachunkowy (2018), nie jest jasne, jak KE zamierza zagwarantować realizację celów środowiskowych i klimatycznych przyszłej WPR. Odnosi się to także do innych celów, które ma realizować WPR. Tę sytuację dobrze podsumował Brunori (2018), który stwierdził, że „Komisja zdefiniowała ogólne cele i uwolniła się od detali”. Problemem mogą być zróżnicowane preferencje co do zakresu i formy ochrony środowiska, które są zróżnicowane między krajami (Millimet, 2014).

Podsumowując, dostosowanie polityki rolnej do uwarunkowań sektora jest konieczne dla stworzenia efektywnego i skutecznego systemu wsparcia rolnictwa oraz włączenia go w proces ograniczania zmian klimatycznych oraz ochronę zasobów naturalnych. Jednakże, aby rozwiązania te nie stały w sprzeczności z funkcjonowaniem jednolitego rynku UE oraz zapewniały wspólne starania o ograniczenie negatywnego wpływu działalności człowieka na środowisko, konieczna jest koordynacja realizowanych działań i współpraca nie tylko między Komisją Europejską i poszczególnymi państwami członkowskimi Unii Europejskiej, ale także między jej regionami, zwłaszcza że, jak wskazują Galarraga i inni 
(2011), wiodące regiony są coraz bardziej aktywne na arenie międzynarodowej w kwestiach dotyczących zmian klimatycznych.

\section{Podsumowanie}

Debata na temat właściwego szczebla tworzenia polityki rolnej, a w tym jej środowiskowych komponentów, trwa i będzie trwać, gdyż nie ma jednego optymalnego w każdym przypadku rozwiązania. Kwestia federalizmu fiskalnego i środowiskowego, w Unii Europejskiej sprowadzona jest do szerszego problemu subsydiarności, czyli przypisania danego problemu do tego szczebla administracji, który ma największe kompetencje do właściwego zajęcia się daną sprawą. Jednak, jak pokazuje praktyka, często samo już określenie, który szczebel administracji dysponuje wiedzą i narzędziami do zajęcia się danym problemem jest nie tylko kwestią sporną, ale także trudną do jednoznacznego określenia.

Wyniki badań dotyczących federalizmu środowiskowego wskazują na to, że nie ma rozwiązania w zakresie podziału kompetencji, które można byłoby uznać za generalnie bardziej preferowane niż pozostałe (Oates, 2001). Oznacza to, iż każdy przypadek musi być analizowany indywidualnie bazując na specyfice kwestii środowiskowych, których dotyczy problem oraz istniejących już regulacjach i zależnościach między poszczególnymi szczeblami administracji.

W tym kontekście proponowane przez Komisję Europejską rozwiązania dotyczące wspólnej polityki rolnej należy uznać za ciekawy eksperyment. Na tym etapie prac nad zmianami trudno jednakże określić, na ile dojdzie do faktycznego, a nie tylko deklaratywnego przekazania państwom członkowskim większej władzy w zakresie kształtowania polityki rolnej na ich obszarze. Ważne będą również skutki takich rozwiązań, zwłaszcza z punktu widzenia kwestii środowiskowo-klimatycznych oraz w odniesieniu do konkurowania poszczególnych państw na jednolitym rynku UE. Należy jednakże zaznaczyć, iż już teraz rolnicy funkcjonują w odmiennych warunkach, jeśli chodzi o system podatkowy, który obok systemu wsparcia, ma kluczowe znaczenie dla uwarunkowań ekonomicznych prowadzenia działalności rolniczej. W związku z tym faktyczne zagrożenie dla funkcjonowania jednolitego rynku może okazać się niewielkie.

Wspólna polityka rolna obejmuje kraje o różnych warunkach klimatycznych, odmiennej strukturze rolnictwa i niejednakowych systemach podatkowych i emerytalnych. W związku z tym ogromnym wyzwaniem jest zaprojektowanie instrumentów, które odpowiadałyby potrzebom tak zróżnicowanego sektora. Z tego względu konieczne jest zaangażowanie państw członkowskich i funkcjonujących w ich ramach regionów w proces dopasowania ogólnych ram i zasad funkcjonowania poszczególnych instrumentów WPR do krajowych i regionalnych uwarunkowań funkcjonowania rolnictwa. Wymaga to koordynacji działań i regulacji prawnych, aby zagwarantować realizację wspólnych dla całej Unii Europejskiej celów ekonomicznych, społecznych i środowiskowych, w tym zwłaszcza zapewnić unijnemu rolnictwu konkurencyjność w skali globalnej.

Podsumowując, można stwierdzić, iż choć wyniki dotychczasowych badań nad federalizmem fiskalnym oraz federalizmem środowiskowym wskazują na dość oczywiste rozwiązanie, czyli określenie podziału kompetencji i uprawnień w zależności od specyfiki danego problemu, to jest to bardzo cenna wskazówka także dla polityki rolnej. Taki wniosek oznacza konieczność głębokiej analizy specyfiki danego problemu w celu 
optymalizacji sposobu zarządzania nim. Warto, zwłaszcza w przypadku polityki rolnej, pamiętać o „trzeciej drodze”, czyli współpracy, która nie musi obejmować tylko współpracy jednostek z jednego szczebla administracyjnego, ale powinna pojawić się również w relacjach wertykalnych między instytucjami na różnych szczeblach władz. Taka współpraca zapewni większą elastyczność w dostosowywaniu się do zmieniających się potrzeb i uwarunkowań prowadzonej polityki rolnej. Należy przy tym podkreślić, iż wynikające ze zmian w otoczeniu oraz z uzyskiwanych doświadczeń we wdrażaniu istniejących rozwiązań wnioski powinny być poparte dowodami, które posłużą modyfikacjom realizowanej polityki i zapewnią tworzenie polityki opartej na dowodach.

\section{Literatura}

Adler, J.H. (2005). Jurisdictional mismatch in environmental federalism. Case Research Paper Series in Legal Studies Working Paper 05-18. DOI: 10.2139/ssrn.770305.

Banzhaf, H.S., Walsh, R.P. (2006). Do People Vote with Their Feet? An Empirical Test of Environmental Gentrification. RFF Discussion Paper No. 06-10. DOI: 10.2139/ssrn.901657.

Brunori, G. (2018). L'implementazione della PAC in Italia nell'ambito del nuovo Piano Strategico Nazionale. Referat wygłoszony podczas Seminario AIEAA - CREA Centro di ricerca Politiche e Bioeconomia Agriregionieuropa „L'agricoltura italiana e il nuovo modello di sostegno della PAC post 2020”, Roma, 30 listopada 2018. Pobrane 10 grudnia z: https://agriregionieuropa.univpm.it/it/system/files/sitecontent/event/ field attachment/2018-10151/gianlucabrunori-7564.pdf.

Corfee Morlot, J. (2009). California in the Greenhouse: Regional Climate Change Policies and the Global Environment. PhD dissertation, Geography Department, University College London, London. Pobrane 15 grudnia $2018 \mathrm{z}$ : https://core.ac.uk/download/pdf/1684959.pdf.

Cortignani, R., Severini, S., Dono, G. (2017). Complying with greening practices in the new CAP direct payments: An application on Italian specialized arable farms. Land Use Policy, 61, 265-275. DOI: 10.1016/j.landusepol.2016.11.026.

Dijkstra, B.R., Fredriksson, P.G. (2010). Regulatory Environmental Federalism. The Annual Review of Resource Economics, 2, 319-339. DOI: 10.1146/annurev-resource-040709-135112.

European Commission (2018d). Proposal for a Regulation of the European Parliament and of the Council establishing rules on support for strategic plans to be drawn up by Member States under the Common agricultural policy (CAP Strategic Plans) and financed by the European Agricultural Guarantee Fund (EAGF) and by the European Agricultural Fund for Rural Development (EAFRD) and repealing Regulation (EU) No 1305/2013 of the European Parliament and of the Council and Regulation (EU) No 1307/2013 of the European Parliament and of the Council, COM(2018)392.

European Court of Auditors (2017). Greening: a more complex income support scheme, not yet environmentally effective. Special Report no. 21/2017. Pobrane 2 listopada 2018 z: https://www.eca.europa.eu/Lists/ECAD documents/SR17 21/SR GREENING EN.pdf.

European Court of Auditors (2018). Opinion No 7/2018 (pursuant to Article 322(1)(a) TFEU) concerning Commission proposals for regulations relating to the Common Agricultural Policy for the post-2020 period (COM(2018) 392, 393 and 394 final). Pobrane 3 grudnia 2018 z: https:/www.eca.europa.eu/ Lists/ECADocuments/OP18_07/OP18_07_EN.pdf.

Ferrara, I., Missios, P. Yildiz, H.M. (2014). Inter-regional competition, comparative advantage and environmental federalism. Canadian Journal of Economics, 47(3), 905-952.

Galarraga, I., Gonzalez-Eguino, M., Markandya, A. (2011). The Role of Regional Governments in Climate Change Policy. Environmental Policy and Governance, 21, 164-182. DOI: 10.1002/eet.572.

Gocht, A., Ciaian, P., Bielza, M., Terres, J.M., Röder, N., Himics, M., Salputra, G. (2017). EU-wide economic and environmental impacts of CAP greening with high spatial and farm-type detail. Journal of Agricultural Economics, 68(3), 651-681. DOI: 10.1111/1477-9552.12217.

Karkkainen, B.C. (2002). Collaborative Ecosystem Governance: Scale, Complexity, and Dynamism. Virginia Environmental Law Journal, 21, 189-206.

Kleijn, D., Rundlof, M., Scheper, J., Smith, H.G., Tscharntke, T. (2011). Does conservation on farmland contribute to halting the biodiversity decline? Trends in Ecology \& Evolution, 26, 474-481. DOI: 10.1016/j.tree.2011.05.009. 
McKenzie, A.J., Emery, S.B., Franks, J.R., Whittingham, M.J. (2013). FORUM: landscape scale conservation collaborative agri-environment schemes could benefit both biodiversity and ecosystem services, but will farmers be willing to participate? Journal of Applied Ecology, 50, 1274-1280. DOI:10.1111/13652664.12122

Merckx, T., Feber, R.T., Riordan, Ph., Townsend, M.C., Bourn, N.A.D., Parsons, M.S., Macdonald, D.W. (2009). Optimizing the biodiversity gain from agri-environment schemes. Agriculture, Ecosystems and Environment, 130, 177-182. DOI: 10.1016/j.agee.2009.01.006.

Millimet, D.L. (2013). Environmental Federalism: A Survey of the empirical literature. Case Western Reserve Law Review, 64(4), 1669-1757.

National Assembly (2018). European Resolution embodying a reasoned opinion on the compliance with the subsidiarity principle of the Proposal for a Regulation of the European Parliament and of the Council establishing rules on support for strategic plans to be drawn up by Member States under the Common Agricultural Policy (COM[2018] 392 final). Pobrane 4 grudnia 2018 z: http://www2.assembleenationale.fr/content/download/71081/724090/version/1/file/European+Resolution+170.pdf

Oates, W.E. (2001). A Reconsideration of Environmental Federalism. Resources for the Future Discussion Paper 01-54. Pobrane 1 listopada 2018 z: https://pdfs.semanticscholar.org/f209/8436fa6cab9d9458619b3ce4076b 749d10f6.pdf.

Prager, K. (2015). Agri-environmental collaboratives for landscape management in Europe. Current Opinion in Environmental Sustainability, 12, 59-66. DOI: 10.1016/j.cosust.2014.10.009.

Sabel, Ch.F., Simon, W.H. (2017). Democratic Experimentalism. W: J. Desautels-Stein, Ch. Tomlins (red.), Searching for Contemporary Legal Thought. Columbia Public Law Research Paper No. 14-549 Cambridge and New York: Cambridge University Press. Pobrane 13 listopada 2018 z: https://ssrn.com/abstract $=2983932$.

Solazzo, R., Donati, M., Tomasi, L., Arfini, F. (2016). How effective is greening in reducing GHG emissions from agriculture? Evidence from Italy. Science of the Total Environment, 573, 1115-1124. DOI: 10.1016/j.scitotenv.2016.08.066.

Steurer, R., Clar, Ch. (2015). Is decentralisation always good for climate change mitigation? How federalism has complicated the greening of building policies in Austria. Policy Sciences, 48, 85-107. DOI 10.1007/s11077014-9206-5.

Tiebout, C.M. (1956). A Pure Theory of Local Expenditures. Journal of Political Economy, 64(5), 416-424. DOI $10.1086 / 257839$

Toderi, M., Francioni, M., Seddaiu, G., Roggero, P.P., Trozzo, L., D’Ottavio, P. (2017). Bottom-up design process of agri-environmental measures at a landscape scale: Evidence from case studies on biodiversity conservation and water protection. Land Use Policy, 68, 295-305. DOI: 10.1016/j.landusepol.2017.08.002.

Van Zeijts, H., Overmars, K., van der Bilt, W., Schulp, N., Notenboom, J., Westhoek, H., Helming, J., Terluin, I., Janssen, S. (2011). Greening the Common Agricultural Policy: impacts on farmland biodiversity on an EU scale (Policy Report No. 500136005). The Hague: PBL Netherlands Environmental Assessment Agency. Pobrane 1 listopada $2018 \mathrm{z}$ : https://www.pbl.nl/en/publications/2011/greening-the-common-agriculturalpolicy-impacts-on-farmland-biodiversity-on-an-eu-scale.

Wieliczko, B. (2015). Współpraca gospodarstw rodzinnych we wdrażaniu działań prośrodowiskowych dotychczasowe doświadczenia wybranych państw i wnioski dla Polski (Cooperation among family farms in implementation of environmental measures - experience of chosen countries and lessons for Poland). W: A. Chlebicka (red. nauk.), Ekonomiczne mechanizmy wspierania i ochrony rolnictwa rodzinnego w Polsce i innych państwach Unii Europejskiej (s. 271-280). Warszawa: Ministerstwo Rolnictwa i Rozwoju Wsi.

Do cytowania / For citation:

Wieliczko B. (2019). Federalizm fiskalny i środowiskowy a polityka rolna. Problemy Rolnictwa Światowego, 19(1), 144-152; DOI: 10.22630/PRS.2019.19.1.13

Wieliczko B. (2019). Fiscal and Environmental Federalism vs. Agricultural Policy (in Polish).

Problems of World Agriculture, 19(1), 144-152; DOI: 10.22630/PRS.2019.19.1.13 